\title{
Identification and evaluation of a potent novel ATR inhibitor, NU6027, in breast and ovarian cancer cell lines
}

\author{
A Peasland ${ }^{1,3}$, L-Z Wang 1,3, E Rowling',3, S Kyle', T Chen', A Hopkins', WA Cliby², J Sarkaria', G Beale', \\ RJ Edmondson' and NJ Curtin*,I \\ 'Newcastle University, Northern Institute for Cancer Research, Newcastle upon Tyne NE2 4HH, UK; ' Department of Radiation Oncology, Mayo Clinic, \\ Rochester, MN 55905, USA
}

BACKGROUND: The ataxia telangiectasia mutated and Rad3-related kinase (ATR) has a key role in the signalling of stalled replication forks and DNA damage to cell cycle checkpoints and DNA repair. It has long been recognised as an important target for cancer therapy but inhibitors have proved elusive. As NU6027, originally developed as a CDK2 inhibitor, potentiated cisplatin in a CDK2independent manner we postulated that it may inhibit ATR.

METHODS: Cellular ATR kinase activity was determined by CHKI phosphorylation in human fibroblasts with inducible dominantnegative ATR-kinase dead expression and human breast cancer MCF7 cells. Cell cycle effects and chemo- and radiopotentiation by NU6027 were determined in MCF7 cells and the role of mismatch repair and p53 was determined in isogenically matched ovarian cancer A2780 cells.

RESULTS: NU6027 is a potent inhibitor of cellular ATR activity $\left(\mathrm{IC}_{50}=6.7 \mu \mathrm{M}\right)$ and enhanced hydroxyurea and cisplatin cytotoxicity in an ATR-dependent manner. NU6027 attenuated G2/M arrest following DNA damage, inhibited RAD5I focus formation and increased the cytotoxicity of the major classes of DNA-damaging anticancer cytotoxic therapy but not the antimitotic, paclitaxel. In A2780 cells sensitisation to cisplatin was greatest in cells with functional p53 and mismatch repair (MMR) and sensitisation to temozolomide was greatest in p53 mutant cells with functional MMR. Importantly, NU6027 was synthetically lethal when DNA single-strand break repair is impaired either through poly(ADP-ribose) polymerase (PARP) inhibition or defects in XRCCI. CONCLUSION: NU6027 inhibits ATR, impairing G2/M arrest and homologous recombination thus increasing sensitivity to DNAdamaging agents and PARP inhibitors. It provides proof of concept data for clinical development of ATR inhibitors.

British Journal of Cancer (20II) 1 05, 372-38I. doi:I0.1038/bjc.20II.243 www.bjcancer.com

Published online 5 July 2011

(c) 201I Cancer Research UK

Keywords: ATR; G2 checkpoint; homologous recombination; chemosensitisation; synthetic lethality

The most commonly used anticancer chemotherapy and radiotherapy kill tumour cells by causing a wide variety of DNA damage. DNA is also continuously damaged by endogenous and environmental agents, with about 10000 endogenous lesions, of which approximately 50 are DSBs, formed per cell cycle (Vilenchik and Knudson, 2003). Efficient cell cycle checkpoint signalling and DNA repair pathways have therefore evolved to preserve cell viability (Jackson and Bartek, 2009). These regulatory proteins represent exciting targets to increase the activity of chemotherapy and radiotherapy (Shrivastav et al, 2008).

Ataxia telangiectasia mutated and Rad3-related (ATR) is a key sensor of single-stranded DNA associated with stalled replication forks, DSB and other DNA damage repair intermediates and is critical for the progression of replication forks stalled by damaged DNA (Petermann and Caldecott, 2006). It is activated by a wide variety of DNA damage and interacts with the mismatch repair (MMR) machinery (Wang and Qin, 2003; Caporali et al, 2004; Yamane et al, 2004; Liu et al, 2010). It functions during the intra-S

*Correspondence: Professor NJ Curtin; E-mail: n.j.curtin@ncl.ac.uk

${ }^{3}$ These authors contributed equally to this work.

Received I April 201।; revised 2 June 201।; accepted 6 June 201 I; published online 5 July $201 \mathrm{I}$ and G2/M checkpoints, via phosphorylation of CHK1, to elicit G2/M arrest (Zou and Elledge, 2003; Kastan and Bartek, 2004; O'Connell and Cimprich, 2005) and stabilises and re-starts stalled replication forks by signalling to the homologous recombination (HR) repair pathway (Chen, 2000; Wang et al, 2004; Sorensen et al, 2005). In mice, homozygous deletion of either ATR or CHK1 confers embryonic lethality, underlying the fundamental importance of this pathway (Brown and Baltimore, 2000). Genetic reduction of ATR abrogates the G2/M checkpoint and increases sensitivity to various cytotoxic anticancer agents (Cliby et al, 1998, 2002; Caporali et al, 2004; Ward et al, 2004; Yamane et al, 2004). Sensitisation is specific to replicating cells and, importantly, ATR inhibition selectively sensitised cells that are defective in the G1 checkpoint, for example, by virtue of p53 mutation (Cliby et al, 1998; Nghiem et al, 2001).

CHK1 inhibitors are being developed for clinical use (Garber, 2005; Chen et al, 2006; Ashwell et al, 2008; Dai and Grant, 2010). As CHK1 is only one of ATR's targets, inhibitors of ATR may have a different spectrum of activity. Despite the attractiveness of the target, small molecule inhibitors of ATR have proved elusive (Wagner and Kaufmann, 2010) and the progress of ATR research has been hampered by the lack of potent inhibitors. The prototype ATR inhibitor, caffeine (Supplementary Figure 1) (Sarkaria et al, 1999) is 
weak and nonspecific (Wagner and Kaufmann, 2010). The PI3K inhibitor PI-103 (Supplementary Figure 1) inhibits ATR but also inhibits ATM and DNA-dependent protein kinase (DNA-PK) (Knight et al, 2006), complicating evaluation of its effect on DNA damage signalling and repair.

The CDK2 inhibitor, NU2058, (Arris et al, 2000), profoundly sensitises cells to cisplatin cytotoxicity independently of CDK2 inhibition (Harrison et al, 2009) and the analogous pyrimidine, NU6027 (2,6-diamino-4-cyclohexyl-methyloxy-5-nitroso-pyrimidine; Supplementary Figure 1) has similar effects (Harrison, 2009). These observations, coupled with the known cisplatin sensitisation by ATR knockdown led us to investigate whether NU6027 inhibited ATR. We determined cellular ATR and CDK2 inhibition by NU6027, modulation of DNA damage-induced cell cycle arrest, repair by HR, enhancement of cytotoxic agents in cells with different p53 and MMR status and explored the synthetic lethality of NU6027 when DNA single-strand break repair is compromised. Our data show that NU6027 is a low micromolar inhibitor of ATR, a novel lead for further drug development and an excellent tool compound for in vitro studies on ATR.

\section{MATERIALS AND METHODS}

\section{Chemicals and reagents}

All chemicals and reagents were supplied by Sigma (Poole, UK), unless otherwise stated. Temozolomide, (Cancer Research UK), doxycyclin, etoposide, paclitaxel, camptothecin, the poly(ADPribose) polymerase (PARP) inhibitor PF-01367338 (formerly known as AG-014699, Pfizer GRD, La Jolla, CA, USA), the CHK1 inhibitor PF-00477736 (Axon MedchemBV, Groningen, The Netherlands), NU6027 and NU6252 (synthesised at Department of Chemistry, Newcastle University, UK; NU6027 is also available from Sigma) were dissolved in DMSO and stored at $-20^{\circ} \mathrm{C}$. Cisplatin, dissolved in saline, and both doxorubicin and hydroxyurea, dissolved in water, were stored at $-20^{\circ} \mathrm{C}$.

\section{Cell lines and culture}

MCF7 human epithelial breast adenocarcinoma cells and L1210 murine leukaemia cells were obtained from American Type Culture Collection (Manassas, VA, USA), Chinese hamster ovary AA8 cells, and EM9 (XRCC1-defective AA8 cells) (Thompson et al, 1980) were a gift from Keith Caldecott, (Sussex University, UK). V-C8 (BRCA2-mutant Chinese hamster lung fibroblasts) (Kraakman-van der Zwet et al, 2003) and V-C8 B2 (BRCA2 reconstructed) were kindly provided by Professor Malgorzata Z Zdzienicka (Leiden University, the Netherlands). GM847KD cells are SV-40transformed normal human fibroblasts stably transfected with doxycyclin-inducible FLAG-tagged, kinase-dead ATR. In the presence of doxycyclin, the kinase dead ATR is expressed and acts as a dominant-negative inhibitor of the native ATR (Cliby et al, 1998, 2002). A2780 ovarian carcinoma cells and its cisplatinresistant derivatives, CP70-B1 and CP70-A2 (Behrens et al, 1987) were a gift from Robert Brown, Beatson Laboratories, Glasgow, $\mathrm{UK}) ; \mathrm{A} 2780$ is p53 and MMR-proficient, CP70 cells lack endogenous MMR because of $h M L H 1$ promoter hypermethylation (Strathdee et al, 1999), CP70-B1 cells have functional MMR because of chromosome 3 transfer, but the CP70-A2 cells carry a transferred chromosome 3 with mutant hMLH1 (Plumb et al, 2006), both CP70 derivatives carry a dominant-negative p53 mutation (Brown et al, 1993; Lu et al, 2001). All cells were cultured in RPMI 1640 medium supplemented with $10 \%$ fetal bovine serum, except the GM847 line, which was grown in Dulbecco's modified Eagle's medium. GM847KD were maintained under antibiotic selection with $400 \mu \mathrm{g} \mathrm{ml}^{-1} \mathrm{G} 418$ sulphate and the CP70-B1 and CP70-A2 cells were grown in $250 \mu \mathrm{g} \mathrm{ml}^{-1}$ hygromycin B
(Invitrogen, Paisley, UK). Cell lines were authenticated by the supplier, used at low passage and were mycoplasma free (MycoAlert; Lonza, Rockland, ME, USA).

\section{PARP activity assays}

Doxycyclin, used to induce ATR-KD expression is reported to inhibit PARP activity (Alano et al, 2006). We therefore determined if doxycyclin inhibits PARP by measuring maximum stimulatable PARP activity in L1210 cells (as used previously to determine PARP inhibitor potency: Griffin et al, 1998) in the presence absence of doxycyclin $\left(2 \mu \mathrm{g} \mathrm{ml}^{-1}\right)$ and in GM847KD cells preincubated or not with doxycyclin $\left(2 \mu \mathrm{g} \mathrm{ml}^{-1}\right)$ for $48 \mathrm{~h}$ before assay. Briefly, cells were permeabilised with digitonin $\left(0.15 \mathrm{mg} \mathrm{ml}^{-1}\right)$ and subsequently exposed to blunt-ended oligonucleotide ( $5^{\prime}$-CGGAAT TCCG-3'; Invitrogen) at $200 \mu \mathrm{g} \mathrm{ml}^{-1}$ in the presence of excess $\mathrm{NAD}^{+}(7 \mathrm{~mm})$ in reaction buffer $(100 \mathrm{~mm}$ Tris- $\mathrm{HCl}, 120 \mathrm{~mm} \mathrm{MgCl}$, $\mathrm{pH}=7.8$ ) for $6 \mathrm{~min}$ at $27^{\circ} \mathrm{C}$. The product, PAR, was detected by immunoblot using the $10 \mathrm{H}$ antibody (Alexander Burkle, University of Konstanz, Germany) by reference to a PAR standard curve as previously described (Plummer et al, 2005).

Poly(ADP-ribose) polymerase activity in exponentially growing GM847KD cells treated or not with doxycyclin $\left(2 \mu \mathrm{g} \mathrm{ml}^{-1}\right)$ for 1 or $24 \mathrm{~h}$, was determined by measuring $N$-methyl- $N^{\prime}$-nitro- $N$-nitrosoguanidine (MNNG, $25 \mu \mathrm{M}$ )-induced cellular $\mathrm{NAD}^{+}$depletion as described previously (Jacobson and Jacobson, 1997).

\section{Cytotoxicity assay}

Cell survival was determined by exposing exponentially growing cells to cytotoxic agents and/or NU6027 for $24 \mathrm{~h}$ before harvesting and seeding triplicate samples for colony formation in drug-free medium. Colonies were fixed, stained with crystal violet $(0.4 \%)$ and counted (Oxford Optronics Ltd, Oxford, UK) and survival expressed as a percentage of the relevant control (vehicle or NU6027 alone).

\section{Western blotting}

Cell lysates $(20-30 \mu \mathrm{g}$ protein) from exponentially growing cells were resolved on $4-20 \%$ polyacrylamide tris/glycine gels (Invitrogen) blotted onto Hybond C-membrane (GE Healthcare UK Ltd, Buckinghamshire, UK) blocked in TTBS buffer $(20 \mathrm{~mm}$ Tris, $140 \mathrm{~mm} \mathrm{NaCl}, 0.1 \%(\mathrm{v} / \mathrm{v})$ Tween-20, $\mathrm{pH} 7.6)$ containing $5 \%$ (w/v) non-fat dried milk and incubated overnight at $4{ }^{\circ} \mathrm{C}$ in antibody buffer (1\% (w/v) non-fat dried milk in TTBS) containing primary antibody: goat anti-ATR, mouse anti-CHK1, rabbit antiDNA-PKcs (Santa Cruz Biotech, Heidelberg, Germany); rabbit anti-CHK1 ${ }^{\mathrm{pS} 317}$ rabbit anti-pCHK1 ${ }^{\mathrm{S} 345}$ (Cell Signalling Tech., Danvers, MA, USA); mouse anti-(FLAG) rabbit anti-pRb ${ }^{\mathrm{T} 21}$ (Invitrogen); mouse anti-pRb (BD Biosciences, Oxford, UK); rabbit anti-pDNA-PKcs ${ }^{\text {s2056 }}$ (Abcam, Cambridge, MA, USA); mouse anti-pATM ${ }^{\text {S1981 }}$ (Millipore, Billirica, MA, USA) and mouse anti-ATM (Thermo Fisher Scientific, Waltham, MA, USA) then with peroxidase-conjugated secondary antibodies (donkey antigoat, goat anti-mouse or goat anti-rabbit, Dako, Glostrup, Denmark) for $1 \mathrm{~h}$, developed using SuperSignal West Pico Chemiluminescent Substrate (Pierce: Thermo Fisher) and quantified (Fuji LAS-3000, Raytech Scientific, Sheffield, UK).

\section{Flow cytometric analysis of drug-treated cells}

Exponentially growing cells were exposed to cytotoxic drugs \pm NU6027 as indicated in the Results section before harvesting and fixing $(70 \%$ ethanol), stained with propidium iodide (CycleTest Plus DNA Reagent Kit; BD Biosciences) and analysed on a FACScan flow cytometer using the CELLQUEST programme (BD Biosciences). 
Immunofluorescent detection of DNA DSB and repair by HR ( $\gamma \mathrm{H} 2 \mathrm{AX}$ and RAD51 focus formation)

Exponentially growing cells on coverslips were treated with PF-01367338 $(10 \mu \mathrm{M})$ for $24 \mathrm{~h}$, fixed with $4 \%$ paraformaldehyde, permeabilised with $0.5 \%$ Triton-X100, $50 \mathrm{~mm} \mathrm{NaCl}, 3 \mathrm{~mm} \mathrm{MgCl}_{2}$, $300 \mathrm{~mm}$ sucrose and $200 \mathrm{~mm}$ HEPES and blocked in $10 \%$ swine serum for $1 \mathrm{~h}$. They were then incubated with mouse anti- $\gamma \mathrm{H} 2 \mathrm{AX}$ (Upstate-Millipore, Billerica, MA, USA) or rabbit anti-RAD51 (H-92, Santa Cruz Biotech) overnight at $4{ }^{\circ} \mathrm{C}$ then with Alexa Fluor 555 goat anti-rabbit IgG or Alexa Fluor 546 goat anti-mouse IgG (Invitrogen) for $1 \mathrm{~h}$ in darkness and mounted onto slides with VectaShield (Peterborough, UK). Images were obtained with a Leica DMR microscope and RT SE6 Slider camera Advanced Spot software version 3.408 (Diagnostic Instruments Inc., Sterling Heights, MI, USA) and analysed using Image J software (NIH public domain software).

\section{Statistical analysis}

Data analysis was performed using GraphPad Prism (GraphPad Software, San Diego, CA, USA). Statistically significant changes were determined using two-tailed paired or unpaired Student's $t$-tests, as appropriate.

\section{RESULTS}

\section{Doxycyclin does not inhibit PARP activity}

Doxycyclin is reported to inhibit PARP activity (Alano et al, 2006). As doxycyclin is used to induce ATR-KD expression, and PARP is a key enzyme in DNA damage signalling and repair, this could significantly compromise analysis of the data. However, we found that doxycyclin $\left(2 \mu \mathrm{g} \mathrm{ml}^{-1}\right)$ did not inhibit PARP activity in L1210 cells or in GM847KD cells pre-incubated for $48 \mathrm{~h}$ with doxycyclin (Figure 1A). Furthermore, exposure of GM847KD cells to doxycyclin for 1 or $24 \mathrm{~h}$ did not inhibit $\mathrm{NAD}^{+}$depletion caused by MNNG-induced activation of PARP. In contrast, the PARP inhibitor, PF-01367338, completely inhibited MNNG-induced $\mathrm{NAD}^{+}$depletion (Figure 1B).

\section{Phosphorylation of CHK1 at ser345 after hydroxyurea is a specific marker of ATR activity}

CHK1 is phosphorylated by ATR at positions ser 317 and 345, however, these may overlap with ATM-mediated phosphorylation events. We therefore measured CHK1 phosphorylation induced by DNA-damaging agents in GM847KD with and without dominantnegative ATR-KD expression. Flag and ATR expression were increased following doxycyclin treatment, confirming ATR-KD induction (Figure 2A). Camptothecin and hydroxyurea, but not etoposide and 5-fluorouracil, induced robust phosphorylation of CHK1. Hydroxyurea-induced phosphorylation at both sites was inhibited when ATR-KD was activated but only ser345 phosphorylation was inhibited in the camptothecin-treated cells. These data demonstrate that $\mathrm{pCHK}^{\mathrm{S} 345}$ is specific for ATR and that camptothecin-induced DNA damage may activate ATM to phosphorylate pCHK1 on Ser317 but hydroxyurea-mediated damage is signalled to CHK1 only via ATR.

\section{NU6027 is a more potent inhibitor of ATR than CDK2 in intact cells and does not inhibit cellular DNA-PK or ATM}

Using $\mathrm{pCHK}^{\mathrm{S} 345}$ as a marker, we measured ATR inhibition by NU6027 in GM847KD and human breast cancer, MCF7 cells (Figures $2 \mathrm{~B}$ and $\mathrm{C}$ ). In GM847KD cells, the $\mathrm{IC}_{50}$ was $2.8 \mu \mathrm{M}$ (single experiment) and in MCF7 cells it was $6.7 \pm 2.3 \mu \mathrm{M}$ (mean \pm s.d. of
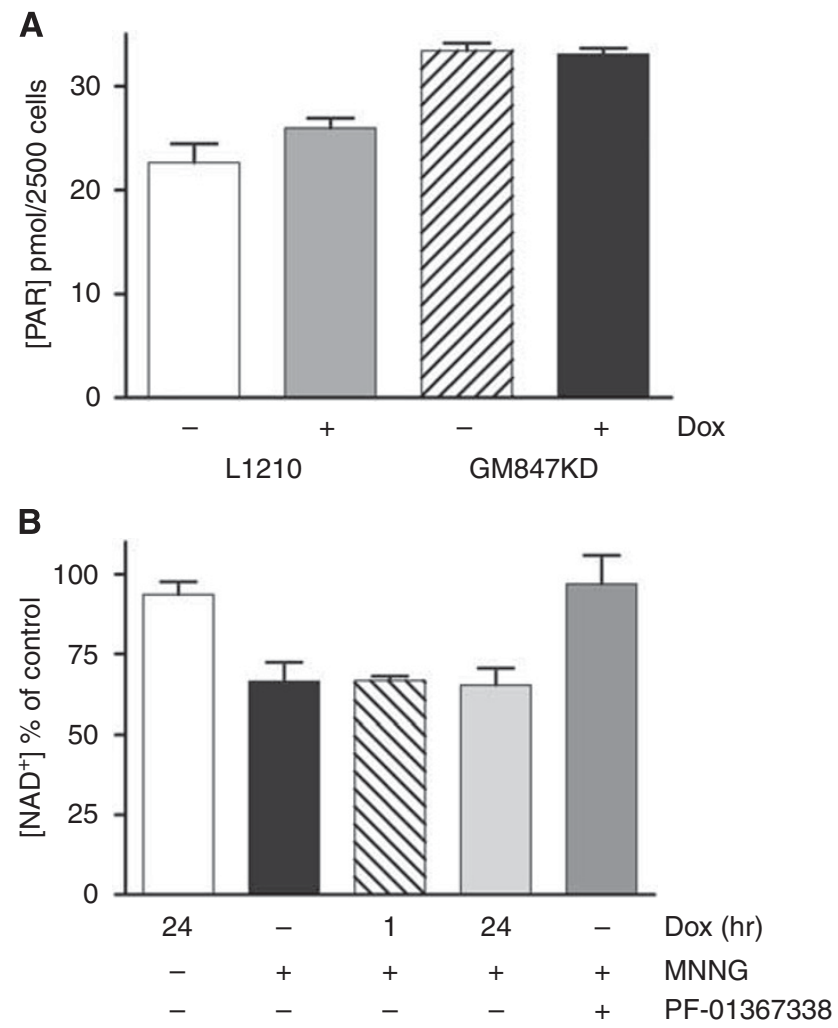

Figure I Doxycyclin does not inhibit PARP activity. (A) Poly(ADPribose) polymerase activity in LI 210 cells in the presence (grey bars) or absence (white bars) of doxycyclin $\left(2 \mu \mathrm{g} \mathrm{ml}^{-1}\right)$ and in GM847KD cells exposed (black bars) or not (hatched bars) to doxycyclin $\left(2 \mu \mathrm{g} \mathrm{ml}^{-1}\right)$ for $48 \mathrm{~h}$. Data are mean and s.e.m. of triplicate samples in a single experiment. (B) N-methyl-N'-nitro- $N$-nitrosoguanidine-induced NAD ${ }^{+}$consumption in GM847KD cells exposed to doxycyclin $\left(2 \mu \mathrm{g} \mathrm{ml}{ }^{-1}\right)$ for I or $24 \mathrm{~h}$ before or treated for I h with the PARP inhibitor PF-0I367338 (I $\mu \mathrm{M})$. Data are no drug (white bars), MNNG alone (black bars) or MNNG in cells pretreated for I $\mathrm{h}$ (hatched bars) or $24 \mathrm{~h}$ (light grey bars) with doxycyclin $\left(2 \mu \mathrm{g} \mathrm{ml}^{-1}\right)$ or I h with PF-0I367338 (I $\mu \mathrm{M}$, dark grey bars), mean and s.e.m. of three independent experiments.

three independent experiments). NU6027 was a less potent inhibitor of CDK2 and $10 \mu \mathrm{M}$ NU6027 inhibited CDK2-mediated $\mathrm{pRb}^{\mathrm{T} 821}$ by $42 \pm 27 \%$ compared with $70 \pm 12 \%$ inhibition of $\mathrm{pCHK}^{\mathrm{S} 345}$ (mean \pm s.d. of three independent experiments). In cell-free biochemical assays, the $\mathrm{IC}_{50}$ of NU6027 against CDK2 is $2.2 \mu \mathrm{M}$ (Arris et al, 2000) and the Ki against ATR is $100 \mathrm{nM}$ (evaluated as described by Charrier et al, 2011: single estimation, John Pollard, Vertex Pharmaceuticals, personal communication). To confirm that NU6027 chemo and radiosensitisation was not due to inhibition of ATM or DNA-PK, we exposed MCF7 cells to IR $(10 \mathrm{~Gy})$ in the presence or absence of NU6027. NU6027 (2 h preexposure and $1 \mathrm{~h}$ post IR exposure to 4 or $10 \mu \mathrm{M}$ ) did not inhibit IR-induced autophosphorylation of DNA-PK (pDNA-PKcs ${ }^{\text {s2056) }}$ ) or ATM (pATM ${ }^{\mathrm{S1981}}$ ) (Figure 2D).

\section{NU6027 sensitises cells to DNA-damaging therapy by inhibiting ATR}

We used GM847KD cells to verify that chemosensitisation by NU6027 was ATR-dependent. GM847KD cells were significantly more sensitive to both hydroxyurea (2.5-fold; $P=0.006)$ and cisplatin (1.8-fold; $P=0.002$ ) following ATR-KD induction by doxycyclin (Figure 3A and Table 1). NU6027 significantly potentiated hydroxyurea (3.2-fold; $P=0.005$ ) and cisplatin (2-fold; $P=0.02)$ in the absence, but not in the presence of doxycyclin. 
A

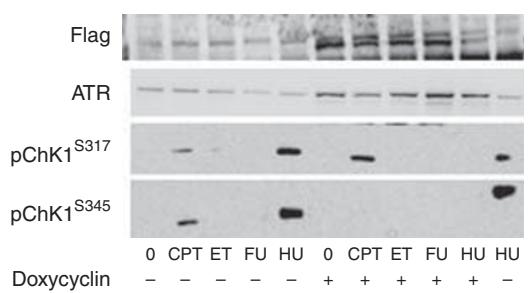

C

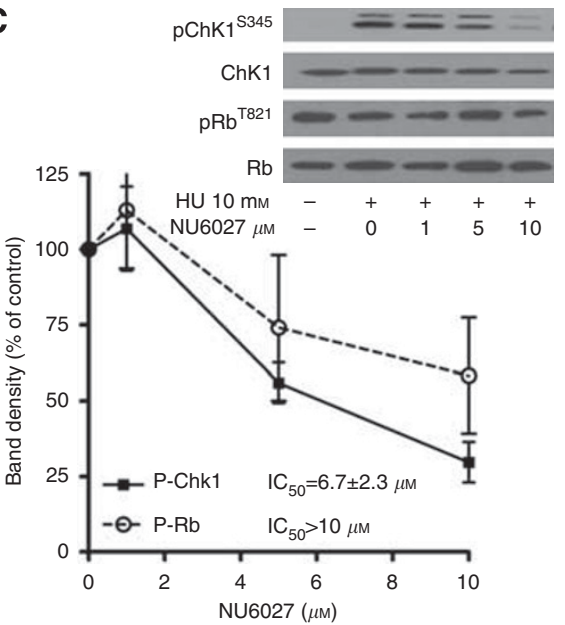

B

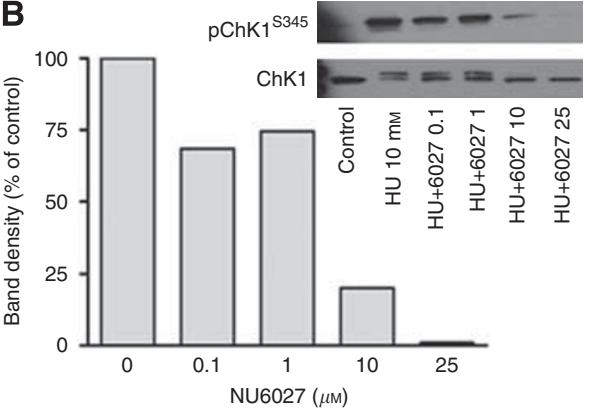

D

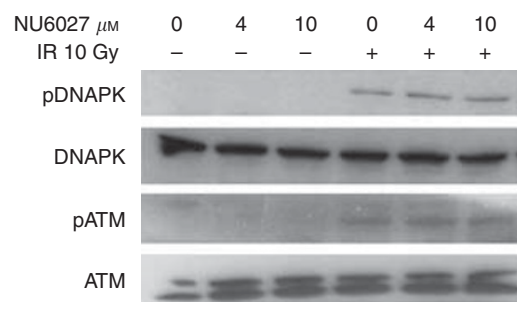

Figure 2 NU6027 inhibits cellular ATR activity, more potently than CDK2 and does not inhibit irradiation-induced DNA-PK or ATM activity. (A) Western blot for $\mathrm{pCHKI}{ }^{\mathrm{S} 317}$ and $\mathrm{pCHKI}{ }^{\mathrm{S} 345}$ in extracts from GM847KD cells exposed to doxycyclin $\left(2 \mu \mathrm{g} \mathrm{ml}^{-1}\right.$, lanes $\left.6-10\right)$ or not $($ lanes I -5 , II) $48 \mathrm{~h}$ before treatment with camptothecin (CPT, $100 \mathrm{nM}$ ), etoposide (ET, I $\mu \mathrm{M}$ ), 5-fluorouracil (FU, $30 \mu \mathrm{M})$ or hydroxyurea (HU, I0 mM) for $24 \mathrm{~h}$. Cell extracts $(20 \mu \mathrm{g})$ were loaded per lane in duplicate gels. After transfer, the membrane was cut horizontally with the top portion incubated with anti-ATR or anti-Flag antibody and the bottom portion incubated with anti-pCHKI ${ }^{\mathrm{S} 317}$ or anti-pCHKI ${ }^{\mathrm{S} 345}$. (B) pCHKI $^{\mathrm{S} 345}$ in $\mathrm{GM} 847 \mathrm{KD}$ cells exposed to 10 mM hydroxyurea in the absence and presence of NU6027 for $24 \mathrm{~h}$. Intensity of $\mathrm{pCHKI}{ }^{\mathrm{S} 345}$ relative to total $\mathrm{CHKI}$ is expressed as a percentage of that determined in cells treated with hydroxyurea alone. (C) MCF7 cells were exposed to 10 mM hydroxyurea in the absence and presence of increasing concentrations of NU6027 for $24 \mathrm{~h}$. Samples were loaded onto a single gel and after cutting horizontally the top portion of the membrane was probed with anti-pRb ${ }^{\text {T2 I I }}$ and the lower with anti-pCHKI ${ }^{\mathrm{S} 45}$ before stripping and re-probing for total Rb or CHKI as appropriate. Intensity of pCHKI ${ }^{\mathrm{S} 345}$ was measured as described above. Similarly, CDK2-specific pRb phosphorylation at T82 I normalised to total pRb is expressed as a percentage of that determined in cells not exposed to NU6027. Data are mean and bars are s.e.m. of 3 independent experiments. (D) Western blot of DNA-PK and ATM and irradiation-induced autophosphorylation in extracts from MCF7 cells pre-exposed or not to NU6027 at 4 or $10 \mu \mathrm{M}$ for $2 \mathrm{~h}$ before and I h after irradiation (I0 Gy).

\section{NU6027 sensitises human breast cancer cells to a wide range of DNA-damaging cytotoxic drugs but not an antitubulin agent}

We investigated chemosensitisation of the major classes of anticancer drugs by NU6027 in MCF7 cells. Cells were exposed to a single concentration of cisplatin (a DNA cross-linking agent), hydroxyurea (an antimetabolite), camptothecin (a topoisomerase I poison), doxorubicin (a topoisomerase II poison) and paclitaxel (an antitubulin agent) in the presence or absence of 4 or $10 \mu \mathrm{M}$ NU6027 (Figures 3Bi-v). To eliminate CDK2 inhibition as a cause of chemosensitisation, we investigated chemosensitisation by a potent CDK2 inhibitor, NU6252 $\left(10 \mu \mathrm{M}\right.$; cell-free $\left.\mathrm{IC}_{50}=19 \mathrm{nM}\right)$ that does not inhibit ATR (Supplementary Figure 2). NU6027 was not cytotoxic at $4 \mu \mathrm{M}$ (survival $>90 \%$ ) and only mildly cytotoxic at $10 \mu \mathrm{M}$ (survival >75\%). As expected, NU6027 (but not NU6252) significantly potentiated cisplatin (1.4-fold; $P=0.059$ at $4 \mu \mathrm{M}$ and 8.7-fold; $P=0.0012$ at $10 \mu \mathrm{M})$, doxorubicin (1.3-fold; $P=0.0079$ at $4 \mu \mathrm{M}$ and 2.5-fold; $P<0.0001$ at $10 \mu \mathrm{M}$ ), camptothecin (1.4-fold; $P=0.0223$ at $4 \mu \mathrm{M}$ and 2-fold; $P=0.018$ at $10 \mu \mathrm{M}$ ) and hydroxyurea (1.8-fold; $P=0.0147$ at $4 \mu \mathrm{m}$ and 0.0412 at $10 \mu \mathrm{M}$ ). Predictably, NU6027 failed to have any impact on paclitaxel-induced cytotoxicity (Figure 3Bv). NU6027 also potentiated $2 \mathrm{~Gy}$ IR in a concentration-dependent manner (Figure 3Bvi, 1.4-fold; $P=0.0126$ at $10 \mu \mathrm{M})$. Potentiation was not related to the degree of cytotoxicity of the primary agent; NU6027 potentiated the cytotoxicity of camptothecin and temozolomide (a DNA methylating agent) at concentrations above and below their $\mathrm{LC}_{50}$ (Figure 3Bvii, 1.8 -fold; $P=0.0008$ at $0.1 \mathrm{~mm}$ temozolomide and 2.7-fold; $P=0.0041$ at $0.5 \mathrm{~mm}$ temozolomide, Figure 3Bviii, 4.7 -fold; $P<0.0001$ at $2 \mathrm{nM}$ camptothecin and 2 -fold at $5 \mathrm{nM}$ camptothecin $P=0.0114)$. In contrast, the CHK1 inhibitor PF- 00477736 at $360 \mathrm{nM}$ as previously described (Blasina et al, 2008) was more cytotoxic in its own right (survival $=45 \%$ ) and caused a 1.6-fold sensitisation of cisplatin $(P=0.008)$ but no significant sensitisation of camptothecin or paclitaxel, in contrast to the previously described disruption of the mitotic checkpoint as well as the DNA damage checkpoint (Zhang et al, 2009) (Supplementary Figure 3).

\section{NU6027 enhancement of cisplatin and, temozolomide cytotoxicity and attenuation of G2/M arrest in cells with different p53 and MMR status}

Functional MMR is necessary for the signalling of temozolomideinduced DNA damage. Mismatch repair-defective cells are resistant to temozolomide and cisplatin. We therefore investigated the effect of NU6027 on cell cycle arrest and cytotoxicity of these agents in human ovarian cancer cells with differing MMR and p53 status; A2780 (MMR + and p53 + ), CP70-B1 (MMR +, p53-) and 
A
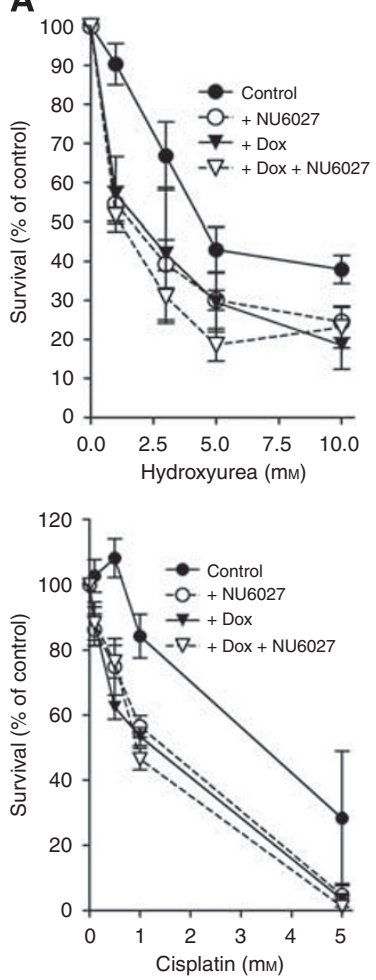

B

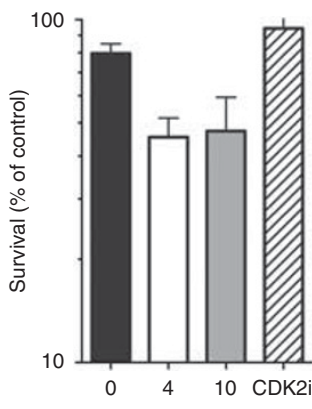

(v) $5 \mathrm{~nm}$ paclitaxel

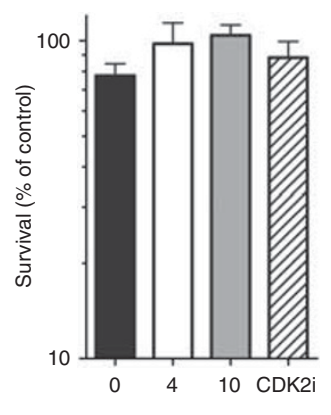

(ii) 2 nм camptothecin

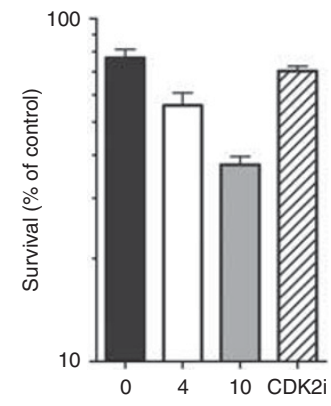

(vi) 2 Gy IR

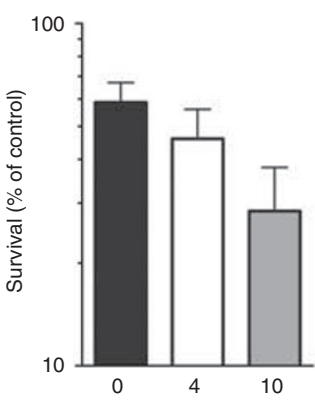

(iii) $1 \mathrm{~nm}$ doxorubicin

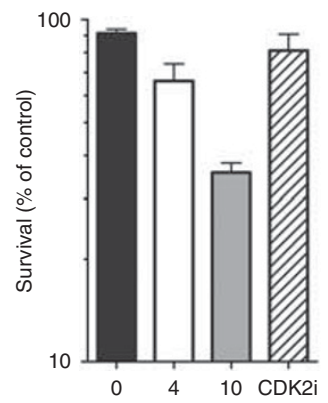

(vii) Temozolomide

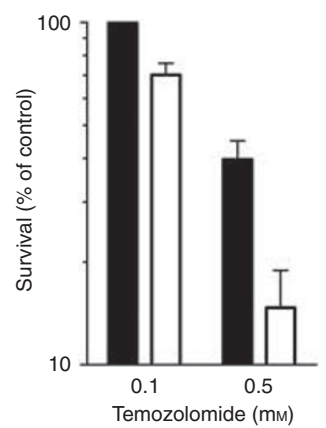

(iv) $\mu \mathrm{m}$ Cisplatin

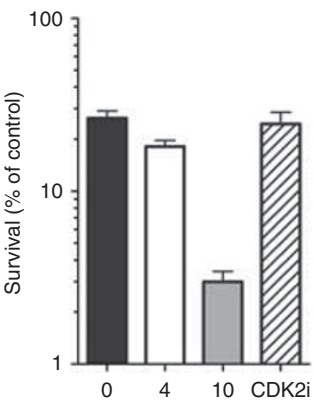

(viii) Camptothecin

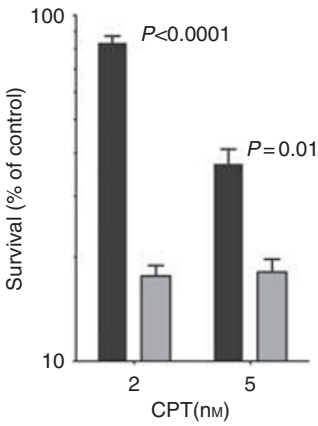

Figure 3 Chemo- and radiosensitisation by NU6027. (A) NU6027 potentiation of hydroxyurea and cisplatin is dependent on ATR activity. Clonogenic survival of GM847KD cells, with (triangles) or without (circles) 48-h exposure to doxycyclin and exposed to increasing concentrations of hydroxyurea or cisplatin in the presence (open symbols) or absence (filled symbols) of $4 \mu \mathrm{M}$ NU6027 for $24 \mathrm{~h}$. Data, normalised to DMSO control or NU6027 alone control as appropriate, are mean and s.e.m. of 3 independent experiments. (B) NU6027 decreases the survival of MCF7 cells exposed to various DNA-damaging agents but not an antitubulin agent. Clonogenic survival of cells exposed for $24 \mathrm{~h}$ to cytotoxic agent alone (black bars) or in the presence of $4 \mu \mathrm{M}$ NU6027 (white bars) or $10 \mu \mathrm{M}$ NU6027 (grey bars) or $10 \mu \mathrm{M}$ NU6252 (CDK2i; hatched bars) to control for CDK2-mediated effects. Data, normalised to DMSO control or NU6027 alone control as appropriate, are mean and s.e.m. of three independent experiments (i-vi) or mean of three replicates in two independent experiments (vii and viii) normalised to vehicle alone, NU6027 or NU6252 alone controls.

Table I Effect of activation of kinase dead ATR in GM847KD cells and co-incubation with NU6027 on the cytotoxicity of cisplatin and hydroxyurea and synthetic lethality with PARP inhibition

\begin{tabular}{lccc}
\hline & \multicolumn{3}{c}{$\mathbf{L C}_{\mathbf{5 0}}$} \\
\cline { 2 - 4 } & $\begin{array}{c}\text { Hydroxyurea } \\
(\mathbf{m m})\end{array}$ & $\begin{array}{c}\text { Cisplatin } \\
(\boldsymbol{\mu} \mathbf{M})\end{array}$ & $\begin{array}{c}\mathbf{P F}-\mathbf{0 1 3 6 7 3 3 8} \\
(\boldsymbol{\mu} \mathbf{M})\end{array}$ \\
\hline Control & $4.8 \pm 1.0$ & $2.65 \pm 0.32$ & $>30$ \\
+Doxycyclin & $1.9 \pm 0.8$ & $1.49 \pm 0.48$ & $12.5 \pm 8.6$ \\
+NU6027 & $1.5 \pm 0.5$ & $1.34 \pm 0.24$ & $13.3 \pm 10.4$ \\
+Doxycyclin+NU6027 & $1.2 \pm 0.2$ & $0.99 \pm 0.14$ & $12.3 \pm 8.8$ \\
\hline
\end{tabular}

Abbreviations: ATR = ataxia telangiectasia mutated and Rad3-related; $\mathrm{PARP}=$ poly(ADP-ribose) polymerase. Data are mean \pm s.d. of $\mathrm{LC}_{50}$ values calculated from at least three independent experiments as shown in Figures 2D and 5D.

CP70-A2 (MMR -, p53-) (Figure 4). NU6027 caused a modest G1 arrest in all cells (presumably by virtue of CDK2 inhibition) and was not cytotoxic per se. As expected, cisplatin was much more cytotoxic to the A2780 cells. Cisplatin-induced G2/M arrest was more pronounced in A2780 cells, in line with its greater cytotoxicity. NU6027 attenuated G2/M arrest and, at $10 \mu \mathrm{M}$, caused significant chemosensitisation of all of the cell lines. Chemosensitisation was greatest in the A2780 cells (20-fold; $P=0.012$ ) compared with only 2-fold in the CP70-B1 and CP70-A2 cells $(P=0.027$ and 0.016 , respectively) and A2780 cells were the only ones to be significantly $(P=0.029)$ sensitised by $4 \mu \mathrm{M}$ NU6027.
A2780 cells were sensitive to temozolomide $(200 \mu \mathrm{M})$ and although NU6027 $(10 \mu \mathrm{M})$ caused a further $50 \%$ reduction in survival, this was not statistically significant. The higher concentration of temozolomide $(800 \mu \mathrm{M})$ killed all A2780 cells but around $15 \%$ of CP70-B1 and $60 \%$ CP70-A2 cells survived, indicating that both p53 and MMR have significant roles in temozolomideinduced cell death. NU6027 caused profound and significant enhancement of temozolomide cytotoxicity in CP70-B1 cells at both 4 and $10 \mu \mathrm{M}$ (reduction in survival $=76 \%, P=0.0098$, and $93 \%, P=0.0076$, respectively) but in CP70-A2 cells only $10 \mu \mathrm{M}$ caused a modest but significant enhancement (approximately $40 \%$, $P=0.0351$ ). Temozolomide caused a profound $\mathrm{G} 2 / \mathrm{M}$ arrest in A2780 cells and to a slightly lesser extent in CP70-B1 cells, which was almost totally reversed by NU6027.

\section{NU6027 attenuates G2/M arrest, inhibits HR function and} is synthetically lethal in combination with PARP inhibition

We investigated inhibition of G2/M arrest and HR by NU6027 after cytotoxic exposure in MCF7 cells. Camptothecin caused profound $\mathrm{G} 2 / \mathrm{M}$ arrest, with an increase in the G2/M fraction from $17 \pm 2 \%$ to $43 \pm 6 \%$ (s.d.) (Figure 5A). This arrest was significantly inhibited by NU6027 to $29 \pm 2 \%$ (s.d.). RAD51 focus formation after 24 -h exposure to the PARP inhibitor, PF-01367338, is a reliable indicator of HR function (Mukhopadhyay et al, 2010). We confirmed this in mammalian cells deficient (V-C8) and proficient (V-C8 B2) in BRCA2, an essential component of HR. PF-01367338 caused an approximately three-fold increase in RAD51 foci in the V-C8 B2, but not the V-C8 cells and NU6027 significantly reduced 
A
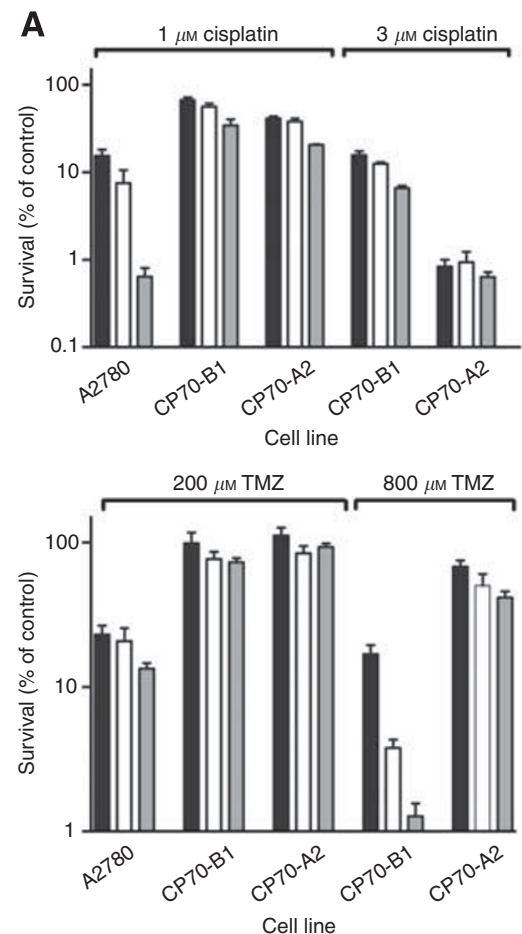

B
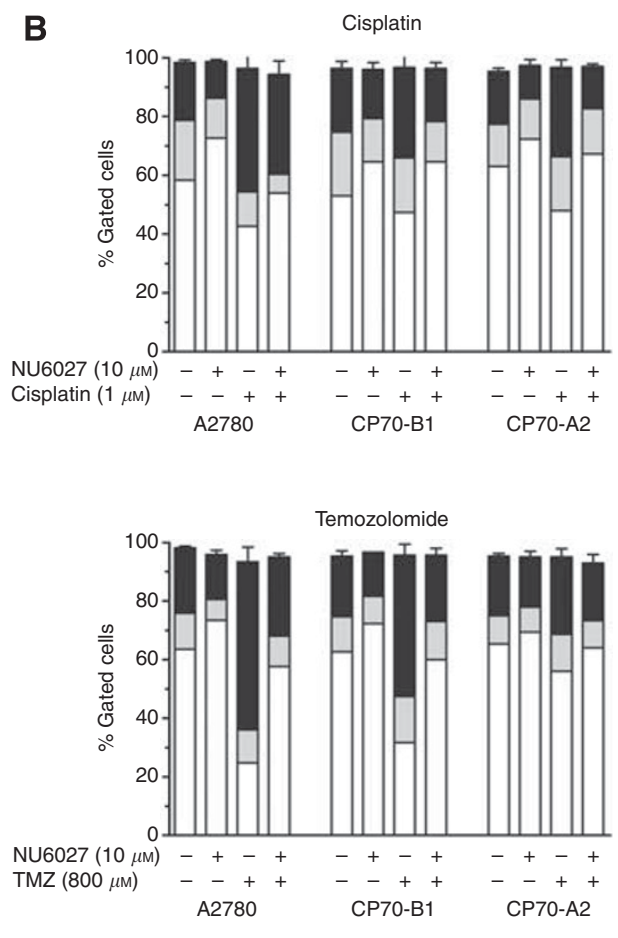

Figure 4 Chemosensitisation and cell cycle effects of NU6027 in ovarian cancer cells with differing p53 and MMR status. (A) Cytotoxicity of cisplatin (top panel), temozolomide (bottom panel) alone (black bars) or in the presence of $4 \mu \mathrm{M}$ NU6027 (white bars) or $10 \mu \mathrm{M}$ NU6027 (grey bars). A2780, CP70-B I and CP70-A2 cells were treated for $24 \mathrm{~h}$. Data, normalised to DMSO control or NU6027 alone control as appropriate, are mean and s.e.m. of three independent colony-formation experiments. (B) Cell cycle distribution of A2780, CP70-BI and CP70-A2 cells treated with cisplatin 24h (top panel), temozolomide $24 \mathrm{~h}$ (bottom panel) alone or in the presence of $10 \mu \mathrm{M}$ NU6027 as indicated. Data are GI (white bars), S (grey bars) and G2/M (black bars), mean and s.e.m. of three independent experiments.

RAD51 foci in both control and PF-01367338-treated V-C8 B2 cells (Supplementary Figure 4). Inhibition of the PARP-dependent repair of endogenous DNA single-strand breaks by PF-01367338 leads to their conversion to double-strand breaks/stalled replication forks during S-phase, triggering $\gamma-\mathrm{H} 2 \mathrm{AX}$ focus formation. In MCF7 cells, PF-01367338 caused a 10-fold increase in $\gamma$-H2AX focipositive cells (Figure 5B). This was accompanied by a three-fold increase in cells with $>5$ RAD51 foci, indicative of HR (Figure 5C). NU6027 had no effect on either $\gamma$-H2AX or RAD51 foci in control cells but in PF-01367338-treated cells NU6027 caused a profound, $82 \%$, and significant $(P=0.0008)$ suppression of the increase in RAD51 foci-positive cells (Figure 5C). Indeed, following exposure to both drugs the number of RAD51-positive cells was not significantly different from baseline levels. NU6027 also caused a modest $36 \%$ reduction in $\gamma-\mathrm{H} 2 \mathrm{AX}$ foci-positive cells, such that there was still a very significantly $(P<0.0001)$ higher level than baseline (Figure 5B). We believe this may be due to CDK2 inhibition leading to fewer cells entering S-phase. The much greater effect on RAD51 than $\gamma$-H2AX suggest that NU6027 compromises HR.

Poly(ADP-ribose) polymerase inhibitors are synthetically lethal in cells lacking HR (Bryant et al, 2005), so we investigated if NU6027 and PF-01367338 exhibited synergistic cytotoxicity in GM847KD cells (Figure 5D, Table 1). The LC $_{50}$ of PF-01367338 was reduced from $>30$ to $12 \mu \mathrm{m}$ following ATR-KD induction. NU6027 sensitised the ATR active cells to the same extent $\left(\mathrm{LC}_{50}=11 \mu \mathrm{M}\right)$ but produced no further sensitisation in cells when ATR-KD was induced. Thus, NU6027 is synthetically lethal to PARP-inhibited cells in an ATR-dependent manner. NU6027 also substantially increased PF-01367338 cytotoxicity in MCF7 cells (Figure 5E). The XRCC1-defective EM9 cells (lacking DNA single-strand break repair) were also significantly more sensitive to NU6027 cytotoxicity than their repair-competent parental AA8 cells (Figure 5F).

\section{DISCUSSION}

Genetic knockdown of ATR indicated that a small molecule ATR inhibitor would be useful as radio- and chemosensitisers. Despite the identification of caffeine as a weak ATR inhibitor over 10 years ago (Sarkaria et al, 1999), until recently there were no novel small molecules reported to inhibit ATR. This partially stems from the difficulty in establishing an appropriate high throughput in vitro system, which would presumably also require ATRIP and other components (Wagner and Kaufmann, 2010). Recently, however, Vertex Pharmaceuticals (San Diego, CA, USA) have discovered a potent ATR inhibitor $(\mathrm{Ki}=6 \mathrm{nM})$, which inhibits the phosphorylation of a target peptide by purified ATR, although the details of the assay are not revealed (Charrier et al, 2011). This compound, VE-821, also blocked phosphorylation of CHK1 at ser345 (Reaper et al, 2011). We have taken a different approach, based on the observation that NU2058 and NU6027 sensitised cells to cisplatin independently of their CDK2 inhibitory activity (Harrison, 2009; Harrison et al, 2009). We developed a cell-based assay using ATR kinase-dead cells, and used it to demonstrate that NU6027 is, in fact, a more potent inhibitor of ATR than CDK2 in living cells. The specificity of kinase inhibitors is likely always to be an issue, for instance the effects of LY294002 are frequently still attributed to its activity against PI3K (e.g., Zhang et al, 2010), even when these involve radiosensitivity (Kimple et al, 2010), when LY294002 has long been known to be an equally potent inhibitor of DNA-PK (Izzard et al, 1999). We acknowledge that NU6027 also inhibits CDK2 but have confirmed that chemosensitisation is due to ATR inhibition by the use of ATR-KD cells. Furthermore another, more potent, CDK2 inhibitor that does not inhibit ATR did not potentiate the DNA-damaging agents' cytotoxicity.

We found that NU6027 increased the cytotoxicity of all classes of DNA-damaging agents used in the treatment of cancer: DNA 
A

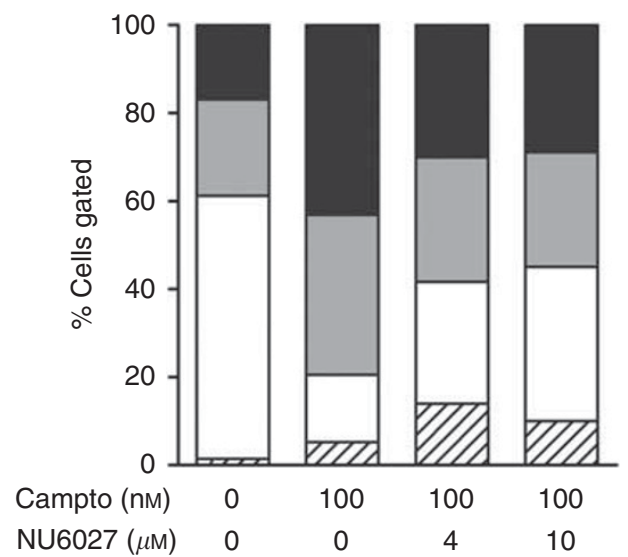

B

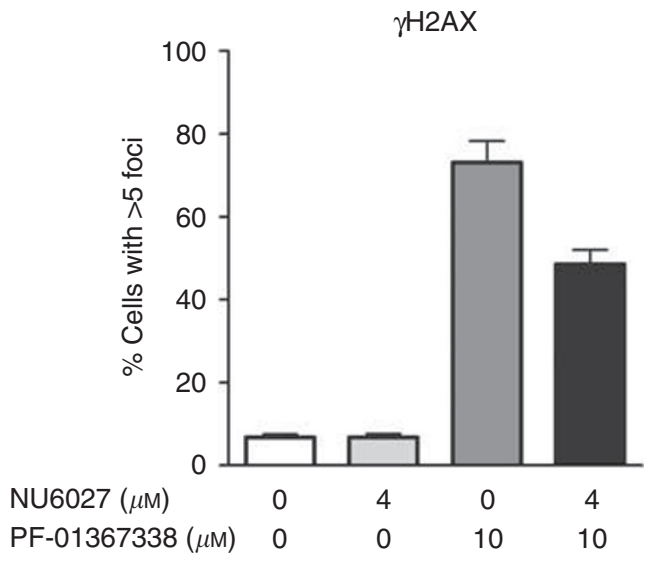

C

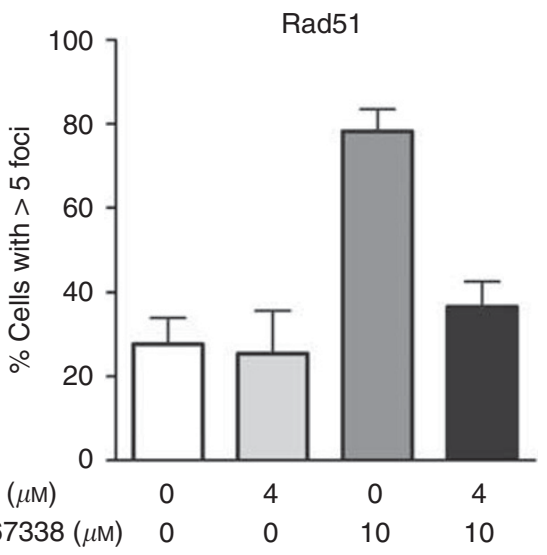

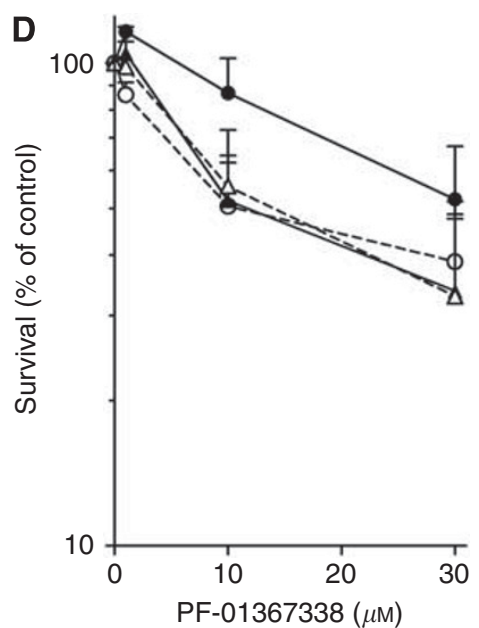
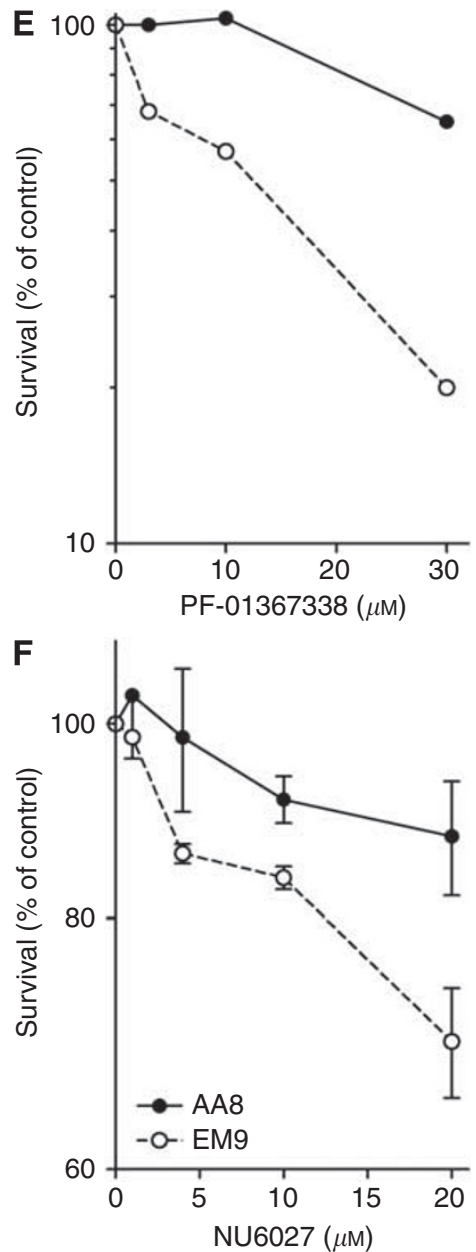

Figure 5 NU6027 attenuated G2/M arrest and inhibits HR in MCF7 cells and is synthetically lethal with a PARP inhibitor and in XRCCI-defective cells. (A) NU6027 attenuates G2/M arrest in MCF7 cells. Cell cycle distribution following 24-h exposure to camptothecin (I00 nM) in the presence or absence of 4 or $10 \mu \mathrm{M}$ NU6027, as indicated. Data are sub-GI (hatched bars), GI (white bars), S (grey bars) and G2/M (black bars). (B) NU6027 mildly inhibits induction of DNA double-strand break by PF-01367338. Cells with > 5 H H2AX foci following exposure to no drug (white bars) NU6027 (4 $\mu \mathrm{M}$ ) alone (pale grey bars) the PARP inhibitor PF-0 367338 (I $0 \mu \mathrm{M}$ ) alone (dark grey bars), or the combination (black bars). Data are mean and s.d. of three independent experiments. (C) NU6027 profoundly inhibits HR. Cells with > 5 RAD5 I foci following exposure to no drug (white bars) NU6027 (4 $\mu \mathrm{M}$ ) alone (pale grey bars) the PARP inhibitor PF$01367338(10 \mu \mathrm{M}$ ) alone (dark grey bars), or the combination (black bars). Data are mean and s.d. of three independent experiments. (D) NU6027 potentiates PF01367338 cytotoxicity in an ATR-dependent manner. Survival of GM847KD cells with (triangles) or without (circles) 48-h doxycyclin induction of ATR-KD, exposed to increasing concentrations of PF-0I 367338 in the presence (open symbols) or absence (filled symbols) of $4 \mu \mathrm{M}$ NU6027 for $24 \mathrm{~h}$. Data are mean and s.e.m. of $>3$ independent experiments. (E) NU6027 potentiates PF-01367338 cytotoxicity in MCF7 cells. Survival of MCF7 cells exposed to increasing concentrations of PF01367338 in the absence (filled circles, solid line) or presence (open circles, broken line) of $4 \mu \mathrm{M}$ NU6027 for $24 \mathrm{~h}$. Data, normalised to DMSO control or NU6027 alone control as appropriate, are mean of duplicate samples in a single representative experiment, of which two were conducted. (F) NU6027 is more cytotoxic to cells lacking XRCCI. Survival of AA8 (filled circles) and EM9 (open circles) cells exposed to increasing concentrations of NU6027 for $24 \mathrm{~h}$ before seeding for colony formation. Data are mean and s.e.m. of triplicate evaluations in two independent experiments. 


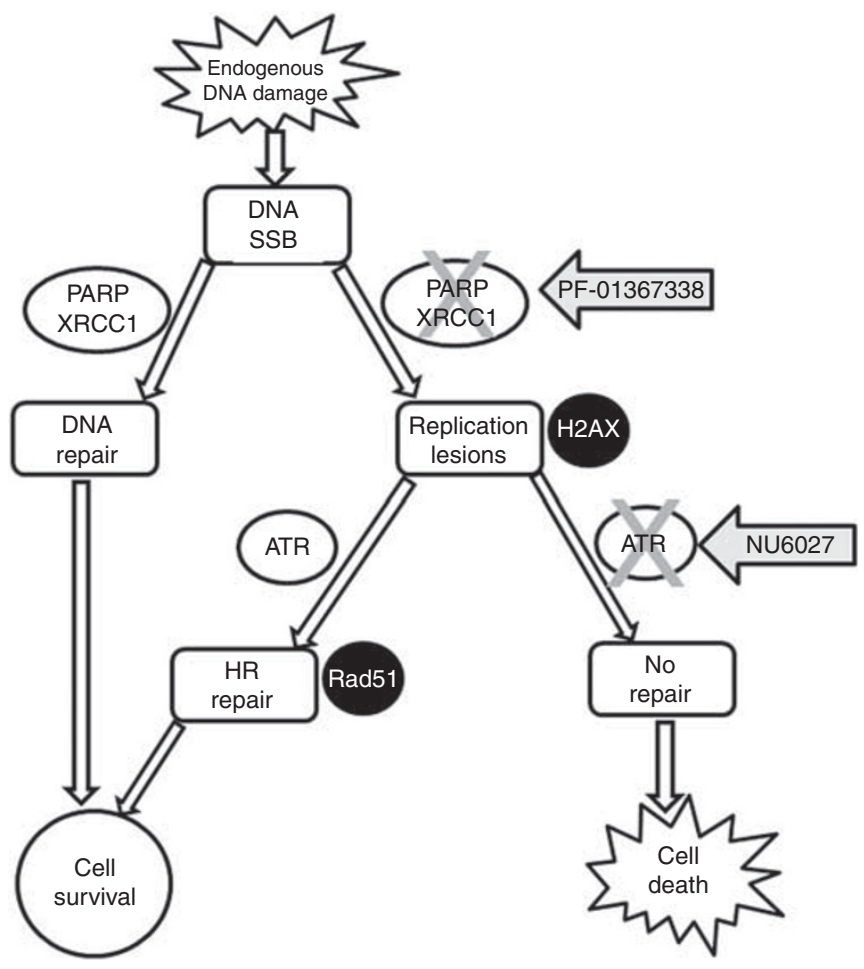

Figure 6 Proposed model for the synthetic lethality of ATR inhibition in cells with inactivated PARP or XRCCI. Endogenously generated DNA damage, largely in the form of single-strand breaks or base damage that is processed to single-strand breaks, are repaired by PARP and XRCCI to promote cell survival. Unrepaired breaks accumulate in the absence of PARP or XRCCI activity leading to stalled replication forks or replicationassociated double-strand breaks (detected by $\gamma \mathrm{H} 2 \mathrm{AX}$ foci), which activate ATR to promotes repair by HR (detected by Rad5 I foci) and cell survival. If ATR is inhibited by NU6027, the replication lesions remain unrepaired and the cell dies.

methylating agents (temozolomide), DNA cross-linking agents (cisplatin), topoisomerase I and II poisons (camptothecin, doxorubicin), antimetabolites (hydroxyurea) and ionising radiation. This was not due to nonspecific chemosensitisation because NU6027 did not enhance the antitubulin agent, paclitaxel, which does not damage DNA. Similarly, the recently identified inhibitor VE-821 enhanced the cytotoxicity of cisplatin, gemcitabine, camptothecin etoposide and IR, but not docetaxel in HCT 116 colon cancer cells (Reaper et al, 2011). The spectrum of NU6027 activity is clearly different from that of the CHK1 inhibitor, PF-00477736 (Supplementary Figure 3 and Zhang et al, 2009). Several CHK1 inhibitors, with different potencies, specificities and activities are currently undergoing clinical trial (reviewed in $\mathrm{Ma}$ et al, 2011) and ATR inhibition is likely to have different therapeutic activity compared with the CHK1 inhibitors.

NU6027 profoundly chemosensitised MCF7 cells, which have wild-type p53 and NU6027 caused a more profound sensitisation of cisplatin in p53 wild-type A2780 cells than p53 mutant CP70-B1 and CP70-A2 cells. We also noted potent chemosensitisation in GM847KD cells, which are SV40 transformed and so lack p53 function. These data do not support the hypothesis that ATR inhibitors should selectively chemosensitise cells with p53 dysfunction. Similarly, the CHK1 inhibitors are active in cells with functional p53 and selectivity for p53 mutant cells may be schedule-dependent (reviewed in Ma et al, 2011). Aberrant G1 control is not solely attributable to p53 but seems to be so common as to be a general characteristic of cancerous cells (Massague,
2004). Selective sensitisation of cells with G1 checkpoint dysfunction by ATR inhibitors may therefore only be seen when comparing normal and cancerous cells. NU6027 does not have sufficient aqueous solubility for in vivo evaluation to address this question but its promising cellular activity provides a sound basis for the development of further inhibitors for more advanced pre-clinical investigations.

NU6027 enhanced the cytotoxicity of temozolomide to a greater extent in CP70-B1 cells than CP70-A2 cells but increased cisplatin cytotoxicity to the same extent. Thus, functional MMR appears to be necessary for temozolomide but not cisplatin sensitisation by an ATR inhibitor. Similarly, ATR activation by BCNU (which, like cisplatin, causes DNA cross-links), was found to be independent of MMR status but temozolomide only activated ATR in MMR competent cells (Cui et al, 2009). These data imply that the roles of p53 and MMR in the sensitisation by ATR inhibition are complex and may be both cell-line and cytotoxic agent dependent.

Most excitingly, we found that NU6027 was synthetically lethal with PARP inhibition and XRCC1 defects. We propose this is due to its negative impact on $\mathrm{HR}$, as demonstrated by the ablation of RAD51 focus induction, combined with the well-established synthetic lethality of PARP inhibitors in cells with HR defects (Reinhardt et al, 2009). We propose (Figure 6) that endogenously generated DNA single-strand breaks go unrepaired in the absence of PARP or XRCC1, leading to replication lesions that activate ATR to promote repair by HR. When ATR is inhibited the lesions persist and cell death ensues. Polymorphisms in XRCC1 are associated with cancer (Kiyohara et al, 2006) and this may be exploitable by ATR inhibition. Other defects in DNA single-strand break repair, for example, those due to aberration in DNA pol $\beta$ are also associated with cancer (Starcevic et al, 2004). Recent data demonstrate that caffeine selectively radiosensitises pol $\beta$-defective cells (Neijenhuis et al, 2010) implicating that ATR inhibition would have broad applicability in cancer. Furthermore, it is well recognised that oncogene activation itself causes stalled/collapsed replication forks, making such cancer cells particularly dependent on ATR for survival (reviewed in Halazonetis et al, 2008) further supporting the notion that ATR inhibitors will be tumour specific.

In conclusion, we have identified NU6027 as a low micromolar inhibitor of ATR activity in human cells. NU6027 sensitises cells to the major classes of DNA-damaging anticancer therapeutics. Importantly, NU6027 is synthetically lethal when DNA singlestrand break repair is impaired either through PARP inhibition or defects in XRCC1. NU6027 represents an important advance in ATR research and will be a useful tool for further studies. Clearly, further investigations are needed to determine tumour selectivity and the safety of ATR inhibitors alone and in combination with DNA-damaging agents before clinical investigations can be contemplated. Nevertheless, these data presented here provide the proof of concept groundwork for subsequent development of ATR inhibitors with the desired pharmacological properties.

\section{ACKNOWLEDGEMENTS}

We gratefully acknowledge Roger Griffin, Celine Cano and Ian Hardcastle, Newcastle Cancer Centre - Medicinal Chemistry, Newcastle University for the provision of NU6027 and NU6252, Zdenek Hostomsky at Pfizer for the provision of PF-01367338, John Pollard at Vertex for assaying inhibition of ATR activity by NU6027 and Cancer Research UK (AP, L-ZW, ER, SK, TC, GB), UK National Health Service (RJE) and UK Higher Education Funding Council (NJC) for financial support.

Supplementary Information accompanies the paper on British Journal of Cancer website (http://www.nature.com/bjc) 


\section{REFERENCES}

Alano CC, Kauppinen TM, Valis AV, Swanson RA (2006) Minocyclin inhibits poly (ADP-ribose) polymerase-1 at nanomolar concentrations. Proc Natl Acad Sci USA 103(25): 9685-9690

Arris CE, Boyle FT, Calvert AH, Curtin NJ, Endicott JA, Garman EF, Gibson AE, Golding BT, Grant S, Griffin RJ, Jewsbury P, Johnson LN, Lawrie AM, Newell DR, Noble ME, Sausville EA, Schultz R, Yu W (2000) Interfacing cell line screening and structural biology in drug discovery: the identification of a novel class of antiproliferative cyclin dependent kinase inhibitors with distinct molecular interactions and tumour cell growth inhibition profiles. J Med Chem 43: 2797-2804

Ashwell S, Janetka JW, Zabludoff S (2008) Keeping checkpoint kinases in line: new selective inhibitors in clinical trial. Expert Opinion Invest Drugs 17: $1331-1340$

Behrens BC, Hamilton TC, Masuda H, Grotzinger KR, Whang-Peng J, Louie KG, Knutsen T, McKoy WM, Young RC, Ozols RF (1987) Characterisation of a cis-diamminedichloroplatinum II resistant human ovarian cancer cell line and its use in evaluation of platinum analogues. Cancer Res 47(2): 414-418

Blasina A, Hallin J, Chen E, Arango ME, Kraynov E, Register J, Grant S, Ninkovic S, Chen P, Nichols T, O'Connor P, Anderes K (2008) Breaching the DNA damage checkpoint via PF-00477736, a novel small molecule inhibitor of checkpoint kinase 1. Mol Can Ther 7(8): 2394-2404

Brown EJ, Baltimore D (2000) ATR disruption leads to chromosomal fragmentation and early embryonic lethality. Genes Develop 14: 397-402

Brown R, Clugston C, Burns P, Edlin A, Vasey P, Vojtsek B, Kaye SB (1993) Increased accumulation of $\mathrm{p} 53$ protein in cisplatin-resistant ovarian cell lines. Int J Cancer 55: 678-684

Bryant HE, Schultz N, Thomas HD, Parker KM, Flower D, Lopez E, Kyle S, Meuth M, Curtin NJ, Helleday T (2005) Specific killing of BRCA2deficient tumours with inhibitors of poly(ADP-ribose)polymerase. Nature 434: $913-917$

Caporali S, Falcinelli S, Starace G, Russo MT, Bonmassar E, Jiricny J, D'Atri S (2004) DNA damage induced by temozolomide signals to both ATM and ATR: role of mismatch repair system. Mol Pharmacol 66: 478-491

Charrier J-D, Durrant SJ, Golec JMC, Kay DP, Knegtel RM, MacCormick S, Mortimore M, O’Donnell ME, Pinder JL, Reaper PM, Rutherford AP, Wang PS, Young SC, Pollard JR (2011) Discovery of potent and selective inhibitors of ataxia telangiectasia mutated and Rad 3 related (ATR) protein kinase as potential anticancer agents. J Med Chem 54: $2320-2330$

Chen J (2000) Ataxia telangiectasia -related protein is involved in the phosphorylation of BRCA1 following deoxyribonucleic acid damage. Cancer Res 60: $5037-5039$

Chen Z, Xiao Z, Gu WZ, Xue J, Bui MH, Kovar P, Li G, Wang G, Tao ZF, Tong Y, Lin NH, Sham HL, Wang JY, Sowin TJ, Rosenberg SH, Zhang H (2006) Selective Chk1 inhibitors differentially sensitize p53-deficient cancer cells to cancer therapeutics. Int J Cancer 119: 2784-2794

Cliby WA, Lewis KA, Lilly KK, Kaufmann SH (2002) S-Phase and G2 arrest induced by topoisomerase I posons are dependent on ATR kinase function. J Biol Chem 277: 1599-1606

Cliby WA, Roberts CJ, Cimprich KA, Stringer CM, Lamb JR, Schreiber SL, Friend SH (1998) Overexpression of a kinase-inactive ATR protein causes sensitivity to DNA damaging agents and defects in cell cycle checkpoints. EMBO J 17: 159-169

Cui B, Johnson SP, Bullock N, Ali-Osman F, Bigner DD, Friedman HS (2009) Bifunctional DNA-alkylator 1,3-bis(2-chloroethyl)-1-nitrosourea activates the ATR-Chk1 pathway independently of the mismatch repair pathway. Mol Pharmacol 75: $1356-1383$

Dai Y, Grant S (2010) New insights into checkpoint kinase I in the DNA damage response signalling network. Clin Can Res 16: 376-383

Garber K (2005) New checkpoint blockers begin human trials. J Natl Cancer Inst 97: 1026-1028

Griffin RJ, Srinivasan S, Bowman K, Calvert AH, Curtin NJ, Newell DR, Pemberton LC, Golding BT (1998) Resistance-modifying agents. 5. Synthesis and biological properties of quinazoline inhibitors of the DNA repair enzyme poly(ADP-ribose) polymerase (PARP). I Med Chem 41: $5247-5256$

Halazonetis TD, Gorgoulis VG, Bartek J (2008) An oncogene-induced DNA damage model for cancer development. Science 319: $1352-1355$

Harrison LRE, Ottley CJ, Pearson DG, Roche C, Wedge SR, Dolan ME, Newell DR, Tilby MJ (2009) The kinase inhibitor O6-cyclohexylmethylyguanine (NU2058) potentiates the cytotoxicity of cisplatin by mechanisms that are independent of its effect on CDK2. Biochem Pharmacol 77: $1586-1592$
Harrison LRE (2009) Optimising treatment with combinations of novel anti-kinase drugs and cytotoxic therapy. $\mathrm{PhD}$ thesis, Newcastle University Izzard RA, Jackson SP, Smith GC (1999) Competitive and noncompetitive inhibition of the DNA-dependent protein kinase. Can Res 59: $2581-2586$

Jackson SP, Bartek J (2009) The DNA damage response in human biology and disease. Nature 461: $1071-1078$

Jacobson EL, Jacobson MK (1997) Tissue NAD as a biochemical measure of niacin status in humans. Methods Enzymol 280: $221-230$

Kastan MB, Bartek J (2004) Cell cycle checkpoints and cancer. Nature 432: $316-323$

Kimple RJ, Vaseva AC, Cox AD, Baerman KM, Calvo BF, Tepper JE, Shields JM, Sartor CI (2010) Radiosensitization of epidermal growth factor/HER (2-positive pancreatic cancer is mediated by inhibition of Akt independent of ras mutational status. Clin Can Res 16: $912-923$

Kiyohara C, Takayama K, Nakanishi Y (2006) Association of genetic polymorphisms in the base excision repair pathway with lung cancer risk: a meta analysis. Lung Cancer 54: 267-283

Knight ZA, Gonzalez B, Feldman ME, Zunder ER, Goldenberg DD, Williams O, Loewith R, Stokoe D, Balla A, Toth B, Balla T, Weiss WA, Williams RL, Shokat KM (2006) A pharmacological map of the PI3-K family defines a role for p110alpha in insulin signalling. Cell 125: $733-747$

Kraakman-van der Zwet M, Wiegant WW, Zdzienicka MZ (2003) Brca2 (XRCC11) deficiency results in enhanced mutagenesis. Mutagenesis 18: $521-525$

Liu Y, Fang Y, Shao H, Lindsey-Boltz L, Sancar A, Modrich P (2010) Interactions of human mismatch repair proteins MutSa and MutLa with proteins of the ATR-CHK1 pathway. J Biol Chem 285: 5074-5082

Lu X-L, Errington J, Curtin NJ, Lunec J, Newell DR (2001) The impact of p53 status on cellular sensitivity to antifolate drugs. Clin Cancer Res 7: $2114-2123$

Ma CX, Janetka JW, Piwnica-Worms H (2011) Death by releasing the breaks: CHK1 inhibitors as cancer therapeutics. Trends Mol Med 17: $1788-1796$

Massague J. G1 cell cycle control and cancer. Nature (2004); 432: 298- 306

Mukhopadhyay A, Elatter A, Cerbinskaite A, Wilkinson SJ, Drew Y, Kyle S, Los G, Hostomsky Z, Edmondson RJ, Curtin NJ (2010) Development of a functional assay for homologous recombination status in primary cultures of epithelial ovarian tumor and correlation with sensitivity to PARP inhibitors. Clin Cancer Res 16: 2344-2351

Neijenhuis S, Verwijs-Janssen M, van den Broek LJ, Begg AJ, Vens C (2010) Targeted radiosensitization of cells expressing truncated DNA polymerase $\beta$. Cancer Res 70: 8706-8714

Nghiem P, Park PK, Kim Y-S, Vaziri C, Schreiber SL (2001) ATR inhibition selectively sensitizes $G_{1}$ checkpoint-deficient cells to lethal premature chromatin condensation. Proc Natl Acad Sci USA 98: $9092-9097$

O'Connell MJ, Cimprich KA (2005) G2 damage checkpoints: what is the turn-on? J Cell Sci 118: 1-6

Petermann E, Caldecott KW (2006) Evidence that the ATR/CHK1 pathway maintains normal replication fork progression during unperturbed $S$ phase. Cell Cycle 5: 2203-2209

Plumb JA, Aherne W, Lee D, Westwood N, O'Brien V, McDonald E, Brown R (2006) MMR201: a novel small molecule that selectively inhibits growth of MLH1 deficient tumor cells. Proc Am Assoc Cancer Res 47, Abs 2435

Plummer ER, Middleton MR, Jones C, Olsen A, Hickson I, McHugh P, Margison GP, McGown G, Thorncroft M, Watson AJ, Boddy AV, Calvert AH, Harris AL, Newell DR, Curtin NJ (2005) Temozolomide pharmacodynamics in patients with metastatic melanoma: DNA damage and activity of repair enzymes O6-alkylguanine alkyltransferase and poly (ADP-ribose) polymerase-1. Cancer Res 11: 3402-3409

Reaper PM, Griffiths MR, Long JM, Charrier JD, Maccormick S, Charlton PA, Golec JM, Pollard JR (2011) Selective killing of ATM- or p53-deficient cancer cells through inhibition of ATR. Nat Chem Biol; e-pub ahead of print 13 April 2011

Reinhardt HC, Jiang H, Hemann MT, Yaffe MB (2009) Exploiting synthetic lethality for targeted cancer therapy. Cell Cycle 8: 3112-3119

Sarkaria JN, Busby EC, Tibbetts RS, Roos P, Taya Y, Karnitz LM, Abraham RT (1999) Inhibition of ATM and ATR kinase activities by the radiosensitizing agent, caffeine. Cancer Res 59: 4375-4382

Shrivastav M, De Haro LP, Nickoloff JA (2008) Regulation of DNA doublestrand break repair pathway choice. Cell Res 18: 134-147

Sorensen CS, Hansen LT, Dzigielowski J, Syljuåsen RG, Lundin C, Bartek J, Helleday T (2005) The cell-cycle checkpoint kinase CHK1 is required for 
mammalian homologous recombination repair. Nature Cell Biol 7: $195-201$

Starcevic D, Dalal S, Sweasy JB (2004) Is there a link between DNA polymerase beta and cancer? Cell Cycle 3: $998-1001$

Strathdee G, MacKean MJ, Illand M, Brown R (1999) A role for methylation of the hMLH1 promoter in loss of hMLH1 expression and drug resistance in ovarian cancer. Oncogene 18: 2335-2341

Thompson LH, Rubin JS, Cleaver JE, Whitmore GF, Brookman KA (1980) screening method for isolating DNA repair-deficient mutants of $\mathrm{CHO}$ cells. Somatic Cell Genet 6: $391-405$

Vilenchik MM, Knudson AG (2003) Endogenous DNA double-strand breaks: production, fidelity of repair, and induction of cancer. Proc Natl Acad Sci USA 100: $12871-12876$

Wagner JM, Kaufmann SH (2010) Prospects for the use of ATR inhibitors to treat cancer. Pharmaceuticals 3: $1311-1334$

Wang H, Wang H, Powel SN, Iliakis G, Wang Y (2004) ATR affecting cell radiosensitivity is dependent on homologous recombination but independent of non-homologous end joining. Cancer Res 64: $7139-7143$
Wang Y, Qin J (2003) MSH2 and ATR form a signalling module and regulate two branches of the damage response to DNA methylation. Proc Natl Acad Sci USA 100: 15387 - 15392

Ward IM, Minn K, Chen J (2004) UV-induced ataxia telangiectasia mutated and RAD3-related (ATR) activation requires replicative stress. J Biol Chem 279: $9677-9680$

Yamane K, Taylor K, Kinsella TJ (2004) Mismatch repair-mediated G2/M arrest by 6-thioguanine involves the ATR-CHK1 pathway. Biochem Biophys Res Commun 318: 297-302

Zhang C, Yan Z, Painter CL, Zhang Q, Chen E, Arango ME, Kuszpit K, Zasadny K, Hallin M, Hallin J, Wong A, Buckman D, Sun G, Qiu M, Anderes K, Christensen JG (2009) PF-00477736 mediates checkpoint kinase 1 signaling pathway and potentiates docetaxel-induced efficacy in xenografts. Clin Can Res 15: $4630-4640$

Zhang H, Chen D, Ringler J, Chen W, Cui QC, Ethier SP, Dou QP, Wu G (2010) Disulfiram treatment facilitates phosphoinositide 3-kinase inhibition in human breast cancer cells in vitro and in vivo. Can Res 70: 3996-4004

Zou L, Elledge SJ (2003) Sensing DNA damage through ATRIP recognition of RPA ssDNA complexes. Science 300: $1542-1548$ 